\title{
La internacionalización de las ciudades (y del régimen municipal)
}

\author{
Miguel Beltrán de Felipe \\ Profesor Titular de Derecho Administrativo \\ Universidad de Castilla-La Mancha
}

\begin{abstract}
Sumario: 1. PLANTEAMIENTO.-2. EL NUEVO PAPEL DE LAS CIUDADES EN LOS SISTEMAS JURÍDICOS INTERNACIONALES Y EN LOS INTERCAMBIOS ECONÓMICOS Y CULTURALES TRANSNACIONALES. A. Las ciudades en el mundo globalizado. B. Las ciudades y el derecho internacional: las ciudades invisibles. C. El nuevo derecho local internacional: el papel emergente de las ciudades en el escenario jurídico y económico internacional. a) Las ciudades como administraciones vinculadas por normas internacionales: la «localización» del derecho internacional; b) Las ciudades como objeto de regulación por el derecho internacional o por organismos internacionales; c) Las ciudades como incipientes sujetos de derecho internacional; d) Las (redes de) ciudades como actores políticos internacionales.-3. AUTOGOBIERNO Y GLOBALIZACIÓN; ¿EL MERCADO COMO CENTRALIZACIÓN O COMO DESCENTRALIZACIÓN?-4. BIBLIOGRAFÍA.
\end{abstract}

\section{PLANTEAMIENTO}

Las páginas que siguen pretenden ser una aproximación al nuevo papel de las ciudades en el contexto jurídico nacional y global. Se trata de una realidad apenas aprehendida por el derecho, o de contornos aun poco definidos por las normas jurídicas, y por ello este ensayo no pretende ser una construcción com-

\footnotetext{
Abreviaturas

APPRI: Acuerdos Bilaterales de Promoción y Protección Recíproca de Inversiones

CCAA: Comunidades Autónomas

CE: Constitución Española

CEAL: Carta Europea de la Autonomía Local

CEDH: Convenio Europeo de Derechos Humanos

CEMR: Consejo Europeo de Municipios y Regiones

CIADI: Centro Internacional de Arreglo de Diferencias Relativas a Inversiones (en ingles ICSID)

CNUDMI: Comisión de las Naciones Unidas para el Derecho Mercantil Internacional (UNCITRAL, en inglés)

DLI: Derecho Local Internacional

IED: Inversión Extranjera Directa

NAFTA: North American Free Trade Agreement

NU: Naciones Unidas

OMC: Organización Mundial del Comercio

ONG: Organización No Gubernamental

PIDCP: Pacto Internacional de Derechos Civiles y Políticos

PIDESC: Pacto Internacional de Derechos Económicos, Sociales y Culturales

TBI: Tratado Bilateral de Inversión

TEDH: Tribunal Europeo de Derechos Humanos

TLC: Tratado de Libre Comercio

UCGL: Unión de Ciudades y Gobiernos Locales

UE: Unión Europea

UNCHS: United Nations Centre for Human Settlements (HABITAT)

UNESCO: United Nations Educational, Scientific and Cultural Organization
} 
pleta desde el punto de vista jurídico. Mi intención es tan solo dar cuenta de algunas manifestaciones relativamente recientes que están alterando el panorama tradicional tanto del derecho internacional como del derecho interno de cada país. Es pues un trabajo en fase de construcción. Y es también posible, como digo, que tal vez se salga un poco del molde habitual de los escritos jurídicos, en la medida en que recoge dinámicas políticas aun no reflejadas en normas jurídicas, o reflejadas sólo tangencialmente en normas propias de lo que en Europa se conoce como soft law o «derecho blando».

Debo hacer un par de advertencias. La primera es que cuando hablo de «las ciudades», me refiero no a cualquier ciudad de cualquier tamaño y de cualquier característica. Me refiero a ciudades que por su peso político, su tamaño, su importancia estratégica, etc., tienen algún tipo de presencia internacional. En realidad «las ciudades» en este trabajo equivale a «las grandes ciudades» partiendo del supuesto, acaso demasiado generalizado, de que las grandes ciudades tienen presencia internacional. De los ejemplos que iré poniendo se deduce el tipo de ciudad al que me refiero. Del mismo modo, voy a emplear el término «ciudad» en lugar del más técnico y preciso «municipios». Por varios motivos: uno de ellos es la sencillez conceptual y del discurso (que evita tener que referirse a «ayuntamiento», «municipio», «pleno municipal», con las distintas variantes técnico-jurídicas propias de cada vocablo). Otro es que en ocasiones las realidades políticas a que aludo bajo el rótulo «ciudades» no encajan en dichas categorías. Por ejemplo el municipio de Barcelona, en España, que como es relativamente pequeño desde el punto de vista de la extensión de su termino municipal, sólo representa alrededor de la mitad de los habitantes del total de la aglomeración metropolitana, y por ello si hablase del municipio de Barcelona, empleando el término municipio en sentido estricto, estaría dejando fuera del análisis al conjunto de la realidad política, económica y social - que es la que me interesa- que representa el área metropolitana de Barcelona ${ }^{1}$. Finalmente, hablo de «ciudades» porque es la única palabra que - por lo menos en español- engloba a todas las denominaciones con que en los distintos países de habla hispana se conoce a las administraciones públicas locales.

\section{EL NUEVO PAPEL DE LAS CIUDADES EN LOS SISTEMAS JURÍDICOS INTERNACIONALES Y EN LOS INTERCAMBIOS ECONÓMICOS Y CULTURALES TRANSNACIONALES}

El punto del que parto es una doble constatación: por un lado la urbanización, y por otro la globalización. Respecto de lo primero, las previsiones de

\footnotetext{
1 Algo parecido sucede con Londres: al margen de los avatares institucionales del órgano de gobierno del área metropolitana (y al margen de la curiosidad histórica de que la City of London es solo una pequeñísima parte del territorio total), cuando hable de Londres me referiré a la conurbación de Londres.
} 
NU-Habitat son que para el año 2050 el $65 \%$ de la población mundial se ubique en el medio urbano, frente al 50\% de comienzos del siglo $21^{2}$. Y respecto de lo segundo, voy a manejar un concepto de globalización que intento sea neutro (lo cual obliga al lector a hacer un esfuerzo de despojarse de otras nociones valorativas o peyorativas). Siguiendo a GIDDENS, o a BECK, por globalización entiendo la circulación por todo el mundo de ideas, productos, capitales y servicios - no tanto de personas - , sin encontrar apenas obstáculos en las fronteras de los Estados, cuya capacidad para llevar a cabo políticas propias se ve notablemente disminuida. Se trata, en síntesis, de mayor interdependencia o interconectividad entre los sistemas político-económicos de los Estados y de disminución del poder de éstos ${ }^{3}$.

Estas dos realidades de urbanización y de globalización son las que enmarcan, y explican, la creciente presencia internacional de las ciudades.

\section{A. Las ciudades en el mundo globalizado}

Lo primero que importa decir es que las grandes ciudades (por lo menos las principales ciudades de un país capitalista, o a nivel mundial las cuarenta o cincuenta ciudades más importantes) son actores en la economía mundial. Lo son al igual que los Estados, las grandes corporaciones, los bancos y entidades financieras, los organismos internacionales, los partidos políticos, etc. La visión tradicional de las ciudades como simples gestoras de servicios de proximidad ya no es cierta (repito: por lo menos para las grandes ciudades a nivel nacional o internacional). Las ciudades piden préstamos a los bancos internacionales, emiten títulos de deuda para financiarse, otorgan subvenciones, sacan a concurso grandes contratos nacionales o internacionales, expropian e indemni-

2 Para México, Jorge Fernández RuIZ señala que a comienzos del siglo 20 la proporción era de $80 \%$ de población rural y $20 \%$ de población urbana, mientras que a comienzos del siglo 21 los datos son los contrarios (20\% de población rural y $80 \%$ de población urbana): Jorge FERNÁNDEZ RUIZ, en «Prólogo» a Manuel JimÉnEZ DORANTES, Constitución y urbanismo, UNAM, México, 2006, pág. XXXI.

3 Fruto de procesos de integración política como la UE, o del poder de los mercados, algunos Estados han incluso perdido los más esenciales atributos de la soberanía (emisión de moneda, defensa, etc.). En este sentido, como ha escrito SASSEN (Saskia Sassen, «De-nationalized state agendas and privatized norm-making», en Kart-Heinz Ladear (ed.), Public Governance in the Age of Globalization, Ashgate, 2004, pág. 51; así como «The State and Globalization: Denationalized Participation», 25 Michigan Journal of International Law 1141 (2004), globalización equivale esencialmente a desnacionalización de la mayoría de decisiones que antes se asociaban con los atributos de la soberanía de los Estados. Siendo el territorio uno de los elementos de la soberanía de las naciones, en realidad más que de desnacionalización deberíamos hablar de desterritorialización: según han puesto de manifiesto los teóricos del pluralismo jurídico, y también las más recientes tendencias del derecho internacional, lo que caracteriza la globalización es que los acontecimientos políticos, sociales y económicos (y las reglas que a ellos se aplican) ya no tienen un fundamento territorial (o geográfico). Tradicionalmente las normas jurídicas se aplicaban en un territorio, determinado por los límites geográficos del Estado que sobre él ejercía su soberanía o su jurisdicción. Hoy ya no. En todo el mundo, los ciudadanos y los gobiernos se ven afectados desde el punto de vista jurídico - en sentido positivo y en sentido negativo- por actividades y decisiones que ocurren y que se toman fuera de las fronteras del Estado. Sobre un mismo territorio se superponen hoy diversas fuentes de poder provenientes de fuera de las fronteras geográficas del Estado. 
zan, etc. Como digo, son actores en la economía mundial, y como todos los demás actores, compiten por recursos económicos escasos, en particular por IED, pública o privada: las ciudades - las más importantes - compiten por inversiones internacionales y por prestigio internacional (buscan hacerse con un nombre en los circuitos turísticos, culturales, económicos, etc.). Podríase decir que «cotizan en bolsa» (en las bolsas de los recursos económicos internacionales). También participan en certámenes internacionales (olimpiadas, exposiciones, otras competiciones sectoriales), incluso compiten por ser sede de eventos o reuniones más o menos públicos y de grandes corporaciones ${ }^{4}$. Y a nivel interno de cada país, las ciudades son un contrapeso a los demás poderes territoriales y un banco de pruebas para experimentos políticos y organizati$\operatorname{vos}^{5}$. También son una plataforma política para los Alcaldes: quien ha sido presidente de la República Francesa entre 1995 y 2007 antes fue Alcalde de París, y el anterior Alcalde de la Ciudad de México estuvo a punto de ser Presidente de la Nación en las elecciones de $2006^{6}$.

Siguiendo a BLANK (2006a: 887), podemos hablar de cuatro manifestaciones de la globalización en las ciudades: a) la inversión extranjera, directa o indirecta, en las ciudades; b) la presencia e influencia de trabajadores extranjeros en las ciudades, debido a fenómenos migratorios; c) las relaciones comerciales

4 Los ejemplos más llamativos son la lucha de las ciudades por ser sede de unas olimpiadas (con los habituales escándalos de corrupción y sobornos, favorecidos por el hecho de que el Comité Olímpico Internacional no es un organismo público y no está sometido a los habituales medios de fiscalización propios de algunos Estados de derecho), o de otros campeonatos como el circuito de la ATP (tenis) o de los torneos de golf. Hay una variante que es particularmente llamativa, porque implica grandes inversiones en terrenos que normalmente son públicos: la construcción (con dinero público) de circuitos de autos o de motos para que las ciudades entren en la puja por entrar en la quincena de ciudades que son sede de carreras de nivel mundial de Fórmula uno o de motociclismo. Este ejemplo es más llamativo que el de las olimpiadas, porque si bien la Fórmula 1 la organiza la FIA (Federación Internacional de Automovilismo) en la práctica el poder lo tiene la asociación de equipos (privada) y la empresa (igualmente privada) propietaria de los derechos de televisión: de modo que una gigantesca inversión pública (la construcción del circuito) termina dependiendo de empresas privadas. Sobre todo esto puede verse GREENE (2003). Existen también otros campos menos conocidos en los que las ciudades compiten entre ellas o con los demás poderes públicos de un Estado: ser depositarias de la herencia de artistas de prestigio, ser localización de rodajes de películas o documentales, o en los EEUU ser sede de equipos de las ligas profesionales de baloncesto, béisbol, fútbol americano o jockey - si bien en los EEUU el hecho de instalarse un equipo en una ciudad depende exclusivamente de la iniciativa privada, es decir, de los propietarios de los equipos.

5 El ejemplo del Greater London Council, en el Reino Unido, es muy ilustrativo. Dominado por los laboristas desde su creación en 1965 (reemplazando un anterior órgano menos desarrollado), fue un centro muy importante de poder político hasta que fue abolido por el gobierno conservador de Thatcher en 1985. Las competencias se reasignaron en un nivel inferior, en los barrios (boroughs). Se daba entonces la situación curiosa de que una de las principales ciudades del mundo se queda sin órgano centralizado de gobierno - y sin alcalde. El Council fue reestablecido por el gobierno de Blair en 2000 con el nombre de Greater London Authority.

6 Hay más ejemplos del peso político relevante de las ciudades: en Italia se ha dado el caso de que algunos Ministros dimitieron voluntariamente para presentarse a elecciones para alcalde de alguna gran ciudad, cargo considerado más importante. Y uno de los más importantes líderes del centro-izquierda ha sido y es alcalde de Roma. En los EEUU quien el momento de escribir estas líneas (octubre de 2007) es uno de los principales candidatos del partido republicano fue antes alcalde de Nueva York. 
y financieras entre ciudades de distintos Estados; y d) la penetración de ideas, símbolos e imágenes extranjeras?

Como es sabido, la inversión extranjera directa (IED) constituye uno de los medios mas importantes con los que los países menos desarrollados incrementan su riqueza, y resulta evidente que esta IED es mucho más visible en las ciudades que en el mundo rural (salvo en las escasísimas ocasiones en las que el mundo rural es económicamente rentable para un inversor extranjero ${ }^{8}$ ). No se trata sólo de que las inversiones extranjeras se centran en las ciudades: a veces el capital extranjero no es que haga negocios en ciudades, es que compra la ciudad misma (cuando el mercado inmobiliario es tan rentable que la inversión no es en títulos sino en bienes inmuebles). La presencia de la inmigración es asimismo característica de las ciudades, en las que las minorías raciales, étnicas o lingüísticas encuentran un acomodo menos difícil. Y por último las relaciones económicas entre ciudades: esto es un fenómeno relativamente reciente, pues data de hace unos quince años, y consiste en que las ciudades de distintos países establecen vínculos y redes culturales, políticas y en última instancia económicas ${ }^{9}$. Estas redes son de muchos tipos: redes de ciudades portuarias, de ciudades llamadas culturales (que intercambian a sus orquestas, cuadros de sus museos, etc.), de capitales de Estados federales, de ciudades que son patrimonio de la humanidad declaradas por la UNESCO, de ciudades con dos o más lenguas oficiales, etc. ${ }^{10}$.

De todas estas transformaciones de las ciudades las más importantes son naturalmente la que tienen que ver con la economía. En un mundo en el que las fronteras se están disipando (para la información, para los capitales, y para las personas ${ }^{11}$ ), las ciudades se han puesto a competir. No solamente porque se les adjudique la celebración de competiciones y reuniones. Se han puesto a competir en los mercados internacionales (a competir por atraer inversiones).

FRUG y BARRON (2006: 9) señalan, siguiendo a Sassen, algunas de las nuevas funciones que las ciudades cumplen en el mundo globalizado: a) son centros de dirección y mando en la economía mundial; b) son la localización estratégicas

\footnotetext{
7 En realidad esto último no ocurre sólo en las ciudades, pero sí ocurre de manera más señalada en las ciudades que en los núcleos no urbanos. En todo caso, sí podemos considerar que esta cuarta manifestación es una consecuencia de las otras tres.

8 Ejemplo de ello es la isla española de Mallorca o la isla italiana de Cerdeña. Ambas son unos de los más importantes centros turísticos de Europa, y su suelo ha sido literalmente comprado por inversores extranjeros (básicamente alemanes, británicos y nórdicos).

9 A través de Cámaras de Comercio, de acuerdos de hermanamiento o de cooperación, de entidades conjuntas de promoción turística, etc.

10 Véase con más detalle lo que diré el párrafo C de este mismo apartado sobre las redes internacionales de ciudades.

11 Para algunas personas, pues para otras - los más pobres - no sólo hay menos fronteras sino que hay más fronteras.
} 
de servicios financieros especializados (empresas de servicios, de inversión, o eventualmente también de fábricas o empresas manufactureras tradicionales; y c) son los mercados en los que se intercambian estos productos y servicios.

Esta categorización no es pacífica entre los autores. Hay quien, probablemente con razón, le achaca que generaliza la realidad de unas pocas ciudades (las llamadas «ciudades globales» o «ciudades mundiales» como Nueva York, Londres, Tokio - sobre todo estas tres - y París, Hong Kong, Nueva Delhi o Singapur, y algunas de otros continentes como Johannesburgo, Río o Ciudad de México) a todas las demás ciudades «medianas» ${ }^{12}$. Y hay quien, igualmente con algo de razón, dice que estas tres funciones de las ciudades en la economía - sobre todo la de ser los mercados de bienes y servicios - no sólo no son nuevas sino que vienen de muy atrás porque representan, precisamente, el surgimiento del derecho mercantil en la Europa medieval ${ }^{13}$.

Sin duda ambas objeciones son certeras. Pero sólo en parte, porque la realidad las desmiente, por lo menos en buena medida. Es cierto que sólo unas pocas ciudades del mundo cumplen la función de actores económicos globales. Pero no lo es menos que esas ciudades son el espejo, el referente en el que se miran muchas más. Cuando una ciudad quiere modernizarse, aprender, avanzar, en muchas ocasiones no mira hacia la región o la nación en la que está: mira hacia otras ciudades (a veces extranjeras), que son su modelo político u organizativo. La «atracción magnética» que, como antes dije, siempre han ejercido las ciudades respecto de las personas, ahora lo ejercen también las «ciudades globales» respecto de las que, por su menor tamaño o influencia, no lo son. De forma que ese comportamiento de actor político y económico de unas pocas ciudades es imitado, o pretende ser imitado, por muchas más. Luego la situación que describen FRUG y BARRON, en la práctica, sí responde a la realidad en el sentido de

\footnotetext{
12 Vuelvo a insistir en que hablar de «las ciudades» en general como actores económicos sería una generalización tal vez incorrecta. En este mismo sentido de diferenciar el tratamiento de las grandes ciudades respecto del tratamiento de las ciudades pequeñas vale la pena recordar que algunos países tienen, dentro de su derecho municipal, reglas especiales para las grandes ciudades. Francia tiene desde hace décadas la llamada «ley PLM» - para París, Lyon y Marsella. España tuvo también hace décadas un régimen especial para Madrid y para Barcelona, y en los últimos años estos estatutos especiales han vuelto a renacer: primero con una reforma parcial de la legislación de régimen local - ley 57/2003 - que estableció determinadas previsiones para ciudades medianas y grandes y luego con leyes que han reconocido la especialidad de Madrid como capital del Estado (ley estatal 22/2006 de capitalidad y régimen especial de Madrid) y de Barcelona (ley catalana 22/1998 de carta municipal de Barcelona). También gozan de un régimen especial la ciudad de Palma (ley balear 23/2006 de capitalidad de Palma de Mallorca). Sobre el régimen de Madrid pueden verse, entre otros, Manuel ARAGÓN «El estatuto de capitalidad de Madrid», Cuadernos de Derecho Local n. 3 (2003), págs. 20 y ss., Jorge FERNÁNDEZ-MIRANDA, El régimen especial de Madrid como gran ciudad y capital del Estado (Ley 22/2006, de 4 de julio), Iustel, Madrid, 2007; Antonio TronCoso (ed.), Comentarios a la ley de capitalidad y régimen especial de Madrid, Aranzadi, Cizur, 2007, así como Luciano PAREJO, Juan Bravo, Cayetano Prieto (eds.), Estudios sobre la Ley de capitalidad y de régimen especial de Madrid, Bosch, Barcelona, 2006.

13 Mediante el cambio trayecticio y los demás títulos valor. Según esta visión, las ciudades siempre han sido centros económicos (en ellas estaban los mercados, entendidos como intercambios a gran escala de bienes por dinero, y ahora están los mercados de valores).
} 
que es o bien el modelo real o bien es el modelo al que se tiende. Y en cuanto a la otra crítica (las ciudades siempre han sido centros de poder económico, en realidad los centros de poder económico), hay que decir que en el capitalismo tradicional los gobiernos locales tenían relativamente poca capacidad de decisión sobre los intercambios económicos ${ }^{14}$. Por el contrario, hoy en día las potestades de fomento, de incentivación económica, de generación de bolsas o nichos de negocios, etc. sí están mucho más disponibles para los gobernantes locales (cosa distinta es que tengan a capacidad de gestión para ejercerlas, o visión política para ejercerlas).

Existe sin embargo una posible objeción a este nuevo papel internacional de las ciudades. Si la globalización implica movilidad sin barreras ni fronteras de las inversiones y negocios a nivel mundial, flujo de información igualmente sin barreras ni fronteras, movimientos migratorios cada vez mayores, en definitiva, deslocalización de los centros de poder y de las decisiones públicas y privadas, ello debería traer como consecuencia que la posición de ventaja de las ciudades respecto del medio rural desaparecería. Ya no hay que «estar» físicamente en la ciudad (o en la gran ciudad) para participar en los mercados de capital internacionales. El soporte físico, la localización geográfica de las actividades habría perdido relevancia, y por ello las ciudades no tendrían motivos para resultar potenciadas por la globalización.

Sin embargo, los teóricos de las «ciudades mundiales», singularmente FRIEDMANN (1995: 317), han puesto de manifiesto que la tendencia contraria es por lo menos igual de cierta. Refiriéndose a las corporaciones multinacionales, señala cómo efectivamente han deslocalizado la producción de muchos bienes pero han recentralizado otras funciones directivas, concentrándolas en grandes ciudades que sean núcleos de poder. Hace cuatro o cinco décadas era más frecuente la existencia de grandes negocios en ciudades medianas, y hoy sencillamente no lo es, por la concentración en las grandes ciudades de servicios muy especializados como los servicios financieros, de relaciones públicas o jurídicos, o por la necesidad cada vez mayor de las empresas de estar físicamente cerca de los núcleos de poder económico, mediático, etc. De manera que la localización importa, más aun cuando algunos de los negocios más rentables del mundo a lo largo de la pasada década (a raíz del crack bursátil de 1992) han estado en el negocio inmobiliario, que es el paradigma no de la globalización sino de su contrario, la localización ${ }^{15}$.

\footnotetext{
14 El poder efectivo lo tenían inicialmente los gremios, y luego las autoridades estatales.
}

15 La relación de las ciudades con el suelo en el que se asientan les ha dado una enorme fuente de financiación, porque en casi todos los modelos urbanísticos el desarrollo de la construcción y de la urbanización pasa por una decisión (legal o ilegal) de las autoridades municipales, y eventualmente regionales. Al respecto puede verse FERNANDES y VARLEY (1998). La ciudad es la «dueña» del suelo, no en el sentido de ser titular de los terrenos pero sí en el de ser dueña de su destino y de su valor económico mediante su clasificación a efectos del urbanismo. Por ello, la ciudad tiene la llave de su propio crecimiento y de la posibilidad de convertir en negocio lo que hasta ese momento no valía nada o no estaba en el mercado. Nótese que la posibilidad 
Estamos ya en condiciones de adelantar una primera conclusión. El papel de las ciudades ha resultado potenciado por la globalización no solo por la gigantesca aceleración del proceso de urbanización sino también porque, al desaparecer en gran medida las barreras, fronteras y aduanas, desaparece también el margen de maniobra de los Estados y aparece el de las ciudades. Al difuminarse o incluso desaparecer gran parte de los atributos de la soberanía que encarnaban los Estados (y que se manifestaban en las fronteras y aduanas), las ciudades -y parcialmente también los entes subnacionales como las regiones, provincias o Estados federados - tienden a ocupar el espacio que ocupaba la soberanía. O por lo menos el poder local es la nueva frontera que emerge cuando desaparece o se debilita la «otra» frontera tradicional.

\section{B. Las ciudades y el derecho internacional: las ciudades invisibles}

Esta creciente presencia de las ciudades en el panorama internacional no encaja del todo en el esquema del derecho internacional. En este apartado voy a intentar poner de manifiesto las fricciones que surgen entre la realidad (las ciudades como actores en las relaciones internacionales) y la situación tradicional en el derecho internacional, en virtud de la cual sólo los Estados tienen reconocida capacidad jurídica para las relaciones internacionales.

Conforme al esquema tradicional, aun vigente en su mayor parte, la regulación de las competencias de las ciudades es algo que atañe al ordenamiento interno de cada Estado y no al derecho internacional. Y, como es notorio, sólo los Estados tienen personalidad jurídica internacional: el ordenamiento jurídico internacional se refiere - además de a organismos internacionales o entes supranacionales con personalidad jurídica internacional-a Estados soberanos ${ }^{16}$. Y para dicho ordenamiento internacional no tiene relevancia que a su vez estén compuestos por otros Estados: al derecho internacional le es indiferente que los Estados estén a su vez subdivididos en otros Estados (o de entidades subnacionales similares con capacidad jurídica interna: provincias, comunidades autónomas, regiones, etc.). El principal texto de derecho internacional, la Convención de Viena sobre Derecho de los Tratados, de 1969, se aplica sólo a Estados. Es más: como señala BROWNLIE (2003: 34 y 433) los escasos tratamientos desde el derecho internacional de las entidades subnacionales (regiones o ciuda-

\footnotetext{
de incorporar suelo al desarrollo urbanístico no pasa únicamente por la construcción residencial: piénsese en polígonos industriales, en centros de transporte o logísticos, o incluso en grandes infraestructuras como aeropuertos.

16 Es uno de los axiomas principales - y también más denunciados por los internacionalistas realistas o críticos - del derecho internacional, y aparece constantemente en los principales textos como la sentencia SS Lotus del Tribunal Permanente Internacional de Justicia de 1927: «El derecho internacional tiene por objeto las relaciones entre Estados independientes y soberanos. En consecuencia, las normas a las que se someten emanan de su libre voluntad y se expresa en tratados e instrumentos de carácter internacional así como en usos generalmente admitidos como reflejo de principios jurídicos» (SS Lotus - Francia v. Turquía, TPJI, 1927, serie A, pág. 18).
} 
des) indican que los Estados responden de las acciones de éstas. Como regla general «ante una demanda por incumplimiento de sus obligaciones internacionales, los Estados o las Federaciones no pueden válidamente alegar reglas internas de reparto de competencias, ni disfunciones en su ordenamiento interno respecto de las entidades subnacionales» (BROWNLIE 2003: 34) ${ }^{17}$.

Los europeos estamos muy acostumbrados a que sean los Estados firmantes de los tratados constitutivos de la UE quienes respondan internacionalmente por hechos que no ha cometido. En el ordenamiento europeo ello es así, de forma inequívoca, de modo que, por ejemplo, los Estados miembros responden ante las autoridades europeas de un déficit excesivo causado por el endeudamiento de los entes subnacionales ${ }^{18}$. Lo mismo ocurre con la actividad normativa: son los Estados miembros quienes asumen ante las autoridades europeas la incorporación al derecho interno de un tipo específico de norma europea (la directiva) que no es autoaplicativa sino que requiere de una operación llamada transposición. Pero en ocasiones el sistema competencial interno hace que, si bien quien transpone al derecho nacional la directiva es el Estado miembro, la real penetración de la norma en el ordenamiento dependa de una actividad normativa o ejecutiva de los gobiernos subnacionales. Ante un incumplimiento de la obligación de transposición, o ante un cumplimiento sólo parcial, los Estados miembros responden aunque no culpa no sea suya. Y lo mismo ocurre en el sistema europeo de derechos humanos: el CEDH garantiza derechos a los ciudadanos, y son los Estados (en la actualidad 47) quienes son signatarios del convenio internacional y se obligan a cumplirlo. Pero esos derechos pueden ser menoscabados por cualquier autoridad pública (municipal o regional), de modo que los Estados miembros son condenados por violaciones de derechos que no han cometido (en el sentido de que la violación provino no del gobierno central o federal sino de una autoridad subnacional $)^{19}$.

17 FrUG y BARRON (2006: 19) señalan que en los EEUU es controvertido si los Estados responden o no de las acciones de las ciudades que contravengan Derecho federal. La sentencia Tennessee v. Lane (2004) parece indicar que sí (o por lo menos que el Congreso tiene competencias para establecer esta responsabilidad), pero en Board of Trustees of the University of Alabama v. Garrett (2001) el Tribunal Supremo había dicho que como regla general los Estados no responden de las ilegalidades federales que cometan las ciudades en ellos ubicadas.

$18 \mathrm{Y}$ a dichas autoridades les es completamente indiferente si existían o no medios en el ordenamiento interno mediante los cuales la Federación hubiese podido vigilar el déficit, o evitarlo, y si, en caso de existir dichos medios, se emplearon o no).

19 El ejemplo de la sentencia del TEDH López Ostra (1994) es muy ejemplificativo. Una ciudadana de Lorca (Murcia) estaba padeciendo graves molestias en su vivienda derivadas de la existencia muy próxima de una empresa de curtidos de piel. La industria no contaba con la obligada licencia municipal. La Sra. LÓPEZ OSTRA acudió a los tribunales alegando que la inactividad del municipio, y la falta de vigilancia, le había causado una vulneración de su derecho a la salud y a la intimidad y a su domicilio. En las sucesivas instancias los tribunales negaron que la acción o inacción municipal hubiese lesionado sus derechos constitucionales (en alguna de estas instancias el ministerio fiscal se mostró de acuerdo con la Sra. LóPEZ OsTRA y solicitó, sin éxito, la estimación de su recurso). Agotadas todas las instancias nacionales, la Sra. LÓPEZ OSTRA acudió al TEDH. En 1994 el TEDH, en un proceso en el que no es parte el municipio (sólo son parte los Estados), acogió las pretensiones de aquella y declaró que se había producido una vulneración del art. 8 del CEDH 
Por ello, si un Estado no quiere verse responsable de lo que hagan o dejen de hacer las regiones o ciudades, en teoría debe formular reserva expresa a las cláusulas de responsabilidad de los tratados e instrumentos internacionales que firme o ratifique. Lo cual plantea, por lo menos como hipótesis, graves problemas: si esta posibilidad de reserva se admite de manera generalizada, el resultado sería que todas o la mayoría de las violaciones del derecho internacional causadas por entes subnacionales quedarían impunes - y no habría nadie a quien imputarle la responsabilidad, pues el Estado la habría declinado expresamente ${ }^{20}$.

Desde la perspectiva de la regulación jurídica de las relaciones internacionales (es decir, desde el derecho internacional), las ciudades no son centros de imputación de derechos ni obligaciones. Como decía Italo CALVINO en un bello libro, son invisibles ${ }^{21}$.

Si ello es así, nada de lo que he expuesto en el apartado anterior sería posible. Las ciudades no tendrían posibilidad legal de actuar en la escena internacional porque el derecho internacional no las reconoce como interlocutoras, ni por tanto como sujetos capaces de contraer derechos y obligaciones.

Sin embargo este modelo tradicional no es del todo cierto, y además está empezando a cambiar.

Que no es del todo cierto lo pone de manifiesto un par de cosas. Primero, que en algunas ocasiones las ciudades sí han tenido algún tipo de reconocimiento internacional. Las en su momento llamadas «ciudades libres» de Cracovia, Shanghai, Danzig, o territorios internacionales como Tánger o Jerusalén, o bajo administración internacional como Kosovo muestra que de vez en cuando el derecho internacional sí admite la presencia de ciudades ${ }^{22}$. Y segundo, que efectivamente hay otras muchas entidades que tienen, de hecho, actividad internacional sin por ello tener personalidad jurídica internacional (y acaso sin tener formalmente reconocidas competencias para dicha actividad internacional). Las Universidades firman acuerdos con Universidades de otros Estados. Son entes públicos, ciertamente, pero ¿las responsabilidades a que dé lugar la ejecución del acuerdo son exigibles en virtud del derecho internacional público, del derecho internacional privado, o del derecho interno de uno o de otro Estado? Las Cámaras de Comercio locales o regionales tienen una clarísima proyección

\footnotetext{
(derecho a que se respete la vida privada y familiar, el domicilio y la correspondencia). Pues bien: si bien la sentencia no atribuye formalmente la culpa a ninguna Administración, condena a España a indemnizar a la Sra. LÓPEZ OSTRA.

20 Por esta razón el Derecho europeo no admite la exención de responsabilidad de los Estados (téngase en cuenta que los ejecutores del Derecho europeo no son sólo los Estados sino las regiones o entes subnacionales, que no responden ante las autoridades europeas).

21 Le città invisibili, Einaudi, Turín, 1972 (hay traducción española: Las Ciudades Invisibles, Minotauro, Barcelona, 1983).

22 Es cierto que todos esos casos responden no a una pauta general sino a circunstancias históricas excepcionales de descolonización, de posguerras o similar.
} 
internacional, y son - por lo menos en España - entes parcialmente públi$\cos ^{23}$. En teoría, las responsabilidades derivadas de la actuación internacional de las Cámaras de Comercio, de las Universidades, o de las ciudades se limitan a responsabilidades entre particulares (empresas o comerciantes) o a responsabilidades entre entes sin duda públicos pero no sometidas al derecho internacional como sujetos de éste. De modo que esta responsabilidad, cuando surgiese, no afectaría a los entes territoriales como Estados, Regiones o ciudades. Pero en realidad la responsabilidad del Estado puede verse comprometida, directa o indirectamente (como en el caso Metalclad, al que más adelante me referiré, o en la UE, en donde como ya hemos visto esto ocurre constantemente ${ }^{24}$ ).

Es verdad que toda esta actividad internacional subnacional o privada no está regulada por el Derecho internacional (entendido como relaciones entre Estados) sino que lleva una vida peculiar, al margen de este, en parte sometida a reglas de derecho internacional privado ${ }^{25} \mathrm{y}$ en parte sometida a reglas de arbitraje (COI). Pero sí puede dar lugar a responsabilidad del Estado, si consiste en el incumplimiento de una obligación que el derecho internacional asigna a los Estados (reglas humanitarias, medioambientales, marítimas, etc.) o incluso si los Estados tenían un deber de vigilancia sobre la actividad internacional de los entes subnacionales.

También ha existido otra veta que ha alterado profundamente el modelo tradicional del derecho internacional (conforme al cual sólo los Estados son sujetos del mismo, de forma que tanto los individuos, como sobre todo los entes subnacionales, son «invisibles»). Me refiero al creciente protagonismo de los ciudadanos. Ya desde 1945 se vino notando una transformación del derecho internacional en el sentido de dotar a los ciudadanos de facultades y derechos respecto de sus Estados, convirtiéndoles, siquiera incipientemente, en actores del derecho internacional ${ }^{26}$. Sin embargo ello se ha acentuado en los últimos años. Desde la creación del TPI por el Tratado de Roma en 1998, en vigor desde 2002, los ciudadanos tienen estatuto de sujetos (activos o pasivos) del derecho penal internacional, y ello supone un cambio importante respecto a la situación descrita por HENKIN (porque no se trata ya de que los ciudadanos acudan a tratados internacionales para reclamar sus derechos contra el Estado al que pertenecen, pleiteando a nivel interno: ahora los ciudadanos pueden utilizar ante tribunales internacionales este conjunto de derechos que les reconoce el ordenamiento internacional).

\footnotetext{
23 Y en países como Francia gestionan un servicio público como los aeropuertos.

24 Existen multitud de ejemplos en los que los Estados han sido condenados por el TJCE, y han tenido que responder patrimonialmente, por conductas de universidades, ciudades y sobre todo Regiones. Y lo mismo con el TEDH (no sólo los Estados pueden vulnerar derechos fundamentales, sino particulares, o universidades o ciudades). Pero sólo son demandados Estados, que responden de todas las vulneraciones de derechos fundamentales que ocurran en su territorio.

25 Por ejemplo los acuerdos de las federaciones de empresarios o de Cámaras de Comercio, o - por lo menos en teoría - los compromisos que asuman las ciudades con el Comité Olímpico Internacional.

26 Véase Louis HENKIN «Human rights and state 'sovereignty"», 25 Georgia Journal of International and Comparative Law 1995-1996, p. 33.
} 
Además de a los ciudadanos, algunos textos internacionales atribuyen un cierto reconocimiento a grupos minoritarios o indígenas ${ }^{27}$, a organizaciones llamadas «de liberación nacional», a entidades privadas o semiprivadas supuestamente sin ánimo de lucro ${ }^{28} \mathrm{o}$ incluso a empresas privadas ${ }^{29}$. Además, la cooperación transfronteriza que emprendan ciudades o regiones está poco a poco desplazando a los Estados como monopolizadores de las relaciones internacionales.

Todo ello pone de manifiesto que poco a poco el tradicional derecho internacional está cambiando, y se está adaptando a las nuevas realidades en las que centros de poder que ya no son los Estados comienzan a adquirir protagonismo. Ello no debe sorprendernos: el derecho internacional está basado en la soberanía de los Estados, y al entrar en crisis dicha soberanía como consecuencia de la globalización o la desnacionalización, ello arrastra a la crisis (o al cambio) al derecho internacional ${ }^{30}$.

Pese a ello, es indudable que el nuevo papel internacional de las ciudades (y del derecho local) no encaja en el modelo tradicional. A continuación veremos algunas manifestaciones de la emergencia de este nuevo derecho local internacional.

\section{El nuevo derecho local internacional: el papel emergente de las ciudades en el escenario jurídico y económico internacional}

Según venimos viendo, lo que aun en fase embrionaria y sin contornos precisos podemos llamar, siguiendo a FRUG y BARRON (2006), «derecho local internacional» - en adelante DLI - surge porque la regulación jurídico-constitucional que une a las ciudades con el Estado al que pertenecen empieza a ser regulada, o afectada, por normas internacionales. La principal manifestación de esta internacionalización del derecho local es la Carta Europea de la Autonomía Local del año $1985^{31}$.

\footnotetext{
27 De forma similar - pero sólo similar - a cómo en los EEUU se reconoce a las tribus indias potestad para tener su propia documentación, ciudades, modos de organización, escuelas, etc.

28 La Cruz Roja, u ONGs (por ejemplo en el caso de la adopción internacional de niños).

29 La inmensa mayoría de los TBI reconocen hoy en día a las personas físicas o jurídicas legitimación para iniciar las acciones legales (procedimiento arbitral) de protección del inversionista. Los casos Tecmed (laudo arbitral dictado en 2004 en el marco de un TBI entre México y una empresa española) y Metalclad (laudo arbitral del capitulo 11 de NAFTA que enfrento a México y a una empresa estadounidense) son ejemplo de cómo los TBI y algunos tratados regionales de integración comercial como NAFTA conceden legitimación a los particulares. También la OMC conoce un mecanismo similar.

30 El derecho internacional surgió históricamente, y aun hoy la va arrastrando, de una inmensa paradoja: por un lado, parte de la soberanía de los Estados, pero por otro lado su objetivo es limitar la libertad (o sea, la soberanía) de los Estados, sometiendo a reglas el recurso a la guerra - y ahora la economía, etc.

31 Aun no puede considerarse que exista un régimen jurídico regulador de las relaciones internacionales de las ciudades (más adelante veremos cómo los pasos que al respecto se han dado son aun muy tímidos, y apenas llegan a la categoría de soft law).
} 
A decir de BLANK (2006a: 889), el resultado de ello es la emergencia de un nuevo centro de poder regulado - aun incipientemente - por el derecho. Las relaciones políticas, económicas, jurídicas ya no son relaciones binarias entre el mundo y los Estados, sino que son relaciones triangulares entre el mundo, los Estados y las ciudades ${ }^{32}$. Dado que los entes subnacionales como regiones o Estados miembros de Estados federales tienen también un papel importante que jugar, en realidad las relaciones ya son cuadrangulares ${ }^{33}$.

Varios autores han sistematizado las formas en las que se exterioriza el DLI. BLANK (2006a: 899 y ss., y 2006b: 266) dice que existen cuatro fuentes de surgimiento del DLI: a) las ciudades como entidades publicas vinculadas por el derecho internacional y por tanto como recipiendiarias de obligaciones (y potestades) internacionales; b) las ciudades como objeto de regulación por entidades transnacionales; c) las ciudades como actores y aplicadores del derecho internacional; y d) las ciudades como participantes en la política internacional. FRUG y BARRON (2006: 23 y ss.) reformulan esto mismo de forma ligeramente distinta. Por un lado estudian los factores de transformación derivados o dependientes de la voluntad de las ciudades. Serían las redes de ciudades internacionales, la política exterior de las ciudades, así como los instrumentos internacionales sobre el autogobierno local. Y por otro lado recogen dos fenómenos que a su juicio no dependen tanto de la voluntad de las ciudades: la (buena) gobernanza local como factor de desarrollo económico, y las ciudades como espacio de derechos fundamentales (y como escenario de una política municipal de derechos fundamentales).

Unos y otro están diciendo más o menos lo mismo, colocando en uno u otro orden e importancia manifestaciones muy similares. Yo creo que se puede sintetizar las dos propuestas del modo siguiente. Este nuevo DLI tendría cuatro ejes principales: a) las ciudades como administraciones públicas vinculadas por normas internacionales; b) las ciudades como objeto de regulación por el dere-

\footnotetext{
32 Y en aquellos Estados como México, Argentina, Chile, etc. en los que una ciudad (la capital) tiene un peso político y económico desproporcionadamente superior al de otras ciudades, en realidad el diagnostico estaría desequilibrado porque esa ciudad es un contrapoder gigantesco que distorsiona el análisis.

33 Hay sin embargo quien como BLANK (2006b: 267) apunta que las regiones tienen una importancia sólo marginal en estas relaciones ¿Qué ha pasado entonces con las regiones o con los Estados miembros de una Federación? ¿Por qué han desaparecido en la práctica del escenario económico y político internacional? Porque todos los Estados federales habían por así decir neutralizado la proyección internacional de los Estados miembros: la evolución de los EEUU, México, Alemania, y otros, había ido justamente hacia la afirmación de la exclusiva competencia nacional para todo lo que tuviese que ver con las relaciones internacionales o con el comercio internacional. De manera que, al desaparecer o difuminarse las fronteras nacionales, lo que aparece no son fronteras internas (las que delimitan la competencia territorial de regiones, provincias o Estados) sino que el único poder que aparece con cierta relevancia internacional son las grandes ciudades. Desde este punto de vista, el único poder emergente es el de las ciudades. Ello no significa que no existan intentos de visibilidad internacional de entes subnacionales (regiones italianas, CCAA en España, Estados en Alemania), muchas veces a través de acuerdos entre ellas, formando un incipiente «derecho internacional interregional» (ÁLVAREZ GONZÁLEZ, 2003). Una perspectiva comparada relaciones internacionales de las entidades subnacionales en Jorge A. SCHIAVON, La política exterior de las entidades federativas: un estudio comparado, Working paper, 2004, CIDE, México.
} 
cho internacional o por organismos internacionales; c) las ciudades como incipientes sujetos de derecho internacional; y d) las (redes de) ciudades como actores políticos internacionales.

A continuación voy a referirme a cada uno de estos cuatro aspectos.

\section{a) Las ciudades como administraciones vinculadas por normas internacionales: la «localización» del derecho internacional}

La creciente importancia del derecho internacional (sobre todo en áreas como el medio ambiente, la inmigración, o algunas áreas de la economía) hace que su proyección descienda hasta el punto de imponer - al menos potencialmente - obligaciones a las ciudades. Repito que no estoy hablando ahora del supuesto en el que las ciudades son llevadas ante tribunales internacionales por vulneración de derecho nacional o de derecho internacional ${ }^{34}$. Se trata ahora de ver cómo los ciudadanos pueden acudir a los tribunales nacionales para exigir de las ciudades el cumplimiento de normas o estándares de derecho internacional, habida cuenta de que muchas normas de derecho internacional - pese a que el interlocutor sea sólo el Estado - vinculan a todos los poderes públicos de ese Estado, incluyendo por tanto a las ciudades ${ }^{35}$.

BLANK (2006a: 901 y ss.) menciona casos en Israel, en Canadá y en los EEUU en los que ciudadanos, o asociaciones ciudadanas, han litigado contra entes locales - en materia esencialmente de derechos fundamentales - alegando no normas del ordenamiento jurídico nacional sino textos de derecho internacional ${ }^{36}$. Otra fuente importante de obligaciones internacionales para las ciudades es el derecho del medio ambiente, singularmente el de la gestión de recursos naturales, por ejemplo la cooperación transfronteriza respecto de ríos, zonas protegidas. Todo esto, que en Europa parece una obviedad (tanto porque los tratados internacionales suelen tener eficacia directa como por la tradición de autonomía local - reforzada por la CEAL), en otros países si representa una relativa novedad ${ }^{37}$.

\footnotetext{
34 Recuérdese el caso López Ostra, resuelto por el TEDH en 1994, aludido en la nota n. ${ }^{\circ} 19$.

35 Entre esta situación a la que ahora me voy a referir y casos como López Ostra existen bastantes diferencias. Tal vez la más significativa sea que en los supuestos a que ahora voy a aludir es al municipio a quien se demanda y es condenado (y por tanto responde patrimonialmente). En casos como López Ostra, la vulneración del Derecho internacional se imputa al Estado, y es el Estado quien responde patrimonialmente en tanto que único sujeto de Derecho internacional.

36 Se trataba generalmente de textos de NU como el PIDCP o el PIDESC.

37 Como por ejemplo los intensos debates en México derivados de la doctrina de la Suprema Corte de Justicia respecto de la aplicación preferente de los tratados internacionales sobre las leyes federales: véase Miguel RÁBAGO DORBECKER, «Aplicación de tratados internacionales por parte de los tribunales mexicanos: algunas observaciones relativas a su efecto directo», Revista Mexicana de Derecho Publico n. ${ }^{\circ} 6$ (2004), págs. 121 a 145; Hugo PEREZCANO DíAZ, «Los tratados internacionales en el orden jurídico mexicano», Anuario Mexicano de Derecho Internacional n. ${ }^{\circ} 7$ (2007).
} 
La principal razón por la que los ciudadanos acuden a los tribunales nacionales invocando frente a las ciudades normas de Derecho internacional puede ser el buscar en el derecho internacional una protección o derecho que no les reconoce, o no les reconoce claramente, el ordenamiento nacional.

Este fenómeno se está viendo reforzado por el llamado principio de subsidiariedad, conforme al cual las decisiones en seno de un ente supranacional como la UE han de tomarse, y ejecutarse, en la medida de lo posible en la instancia administrativa más próxima al ciudadano ${ }^{38}$. Desde este planteamiento, asistimos a algo que podría parecer contradictorio y que señala BLANK (2006b: 279): la «localización» del derecho internacional, conforme al cual en los procesos de integración política internacional la toma de decisiones - de origen nacional y de origen internacional - se hace al nivel más próximo posible al ciudadano, para así evitar los inconvenientes políticos y de gestión derivados de un poder supranacional excesivamente desarrollado y alejado de la realidad. Por lo menos esa es la justificación de fondo del principio de subsidiariedad.

\section{b) Las ciudades como objeto de regulación por el derecho internacional o por organismos internacionales}

Ya dije que, habida cuenta de su falta de personalidad jurídica internacional, el derecho internacional no se ocupaba de las ciudades (ni de otros entes subnacionales como las regiones, provincias, o Estados en los sistemas federales). La descentralización o centralización de un país no era incumbencia del derecho internacional. Esto ha empezado a cambiar en los últimos años.

\footnotetext{
38 En el Derecho de la UE el principio de subsidiariedad tradicionalmente se refería a las relaciones entre los Estados miembros y las autoridades comunitarias, pero ahora ya se le ha incluido, por primera vez, el nivel subnacional. Conforme al art. 5 del Tratado de la Comunidad Europea (versión consolidada publicada en DOCE $n^{\circ}$ C321E de 29 diciembre de 2006), «La Comunidad actuará dentro de los límites de las competencias que le atribuye el presente Tratado y de los objetivos que éste le asigna. En los ámbitos que no sean de su competencia exclusiva, la Comunidad intervendrá, conforme al principio de subsidiariedad, sólo en la medida en que los objetivos de la acción pretendida no puedan ser alcanzados de manera suficiente por los Estados miembros, y, por consiguiente, puedan lograrse mejor, debido a la dimensión o a los efectos de la acción contemplada, a nivel comunitario. Ninguna acción de la Comunidad excederá de lo necesario para alcanzar los objetivos del presente Tratado». Por su parte, el art. I-11 de Proyecto de Constitución Europea (aprobado en 2004 y aun no en vigor porque no ha sido ratificado por un número suficiente de Estados miembros) dice en su párrafo 3: «En virtud del principio de subsidiariedad, en los ámbitos que no sean de su competencia exclusiva la Unión intervendrá sólo en caso de que, y en la medida en que, los objetivos de la acción pretendida no puedan ser alcanzados de manera suficiente por los Estados miembros, ni a nivel central ni a nivel regional y local, sino que puedan alcanzarse mejor, debido a la dimensión o a los efectos de la acción pretendida, a escala de la Unión. Las instituciones de la Unión aplicarán el principio de subsidiariedad de conformidad con el Protocolo sobre la aplicación de los principios de subsidiariedad y proporcionalidad. Los Parlamentos nacionales velarán por el respeto de dicho principio con arreglo al procedimiento establecido en el mencionado Protocolo». En VELASCO (2006) puede verse una síntesis del principio de subsidiariedad, con mención de la amplísima bibliografía y con aplicación al sistema local español.
} 
El primer paso lo dieron las Naciones Unidas en 1976, con la declaración de Vancouver sobre asentamientos humanos (posteriormente rebautizada como Habitat). Tras veinte años poco fructíferos (y basados en la tradicional hegemonía de los Estados en la aplicación de normas internacionales), en 1996 se aprobó en Estambul la segunda declaración Habitat, que esta vez hacía de las ciudades uno de los elementos más importantes - y que hacía de la sostenibilidad ambiental uno de los elementos esenciales. De forma que el más ambicioso programa de las NU para el futuro del planeta tiene a las ciudades como uno de sus principales actores. Ello explica que una de las principales consecuencias de la Agenda Habitat fuera la propuesta, emanada conjuntamente de las NU y de Asociación Mundial de Ciudades (WACLAC), de un borrador de Carta Mundial del Gobierno Local ${ }^{39}$. De momento no ha sido asumida por la Asamblea General, pero el simple hecho de que exista esta iniciativa en las NU representa ya un paso importantísimo: por vez primera, la principal fuente de producción del derecho internacional (las NU) se ocupan del derecho local de los países. Bien es cierto que había un precedente: la Carta Europea de la Autonomía Local, aprobada por el Consejo de Europa en 1985 y con entrada en vigor en $1993^{40}$. El más reciente desarrollo del autogobierno local en las NU se produjo en 2001 y 2002, con la reafirmación por la Asamblea General de que la declaración de Estambul y la Agenda HABITAT serían la política a seguir y con el reforzamiento del programa UNCHS mediante su reconversión en el Programa de NU sobre Asentamientos Humanos (NU-HABITAT) bajo la dependencia del Consejo Económico y Social y en tanto que una más de las 14 agencias especializadas de las $\mathrm{NU}^{41}$.

Esta incorporación del derecho local a las preocupaciones de organismos internacionales o de entes federativos supranacionales (la UE), y a los textos del derecho internacional, es un fenómeno de la máxima importancia, que por sí mismo tiene potencialidad para transformar el panorama de las ciudades en el mundo ${ }^{42}$. Naturalmente, se trata de un camino que acaba de comenzar, y que

\footnotetext{
39 United Nations Center for Human Settlements (UNCHS-Habitat), World Association of Cities and Local Authorities Coordination, Towards a World Charter of Local Self Government: www.gdrc.org/u-gov/charter.html

40 Como señala BLANK (2006a: 912), lo más importante de ambos textos es que, garantizándoles un derecho de participación en los procesos de toma de decisiones que les afecten, intentan proteger a los municipios frente a los gobiernos regionales o nacionales. También contienen otros derechos colaterales: a asociarse para la defensa y promoción de sus intereses comunes, a cooperar entre sí (incluso a nivel internacional), a ser consultados por los gobiernos regionales o nacionales estos quieran aprobar normas que les afecten, y a un cauce procesal para defender ante los tribunales su autonomía.
}

41 Algunas recientes iniciativas de NU y del Banco Mundial se han centrado no tanto en el establecimiento de un marco jurídico para el autogobierno local sino en poner de manifiesto como la gobernanza local es uno de los principales factores de desarrollo: véase la Campaña Global de la Gobernanza Local emprendida en el seno de NU-Habitat (analizada por FRUG y BARRON, 2006: 31 y 32).

42 De hecho en Europa la Carta Europea de la Autonomía Local - CEAL (aprobada en 1985 y en vigor desde 1988), pese a que no contiene mas que un mandato de dar participación a los entes locales en la toma de decisiones en los asuntos que le afectan, empieza a ser manejada por los tribunales como criterio legal para resolver los conflictos jurídicos y constitucionales que enfrentan a los municipios con los gobiernos regiona- 
está lleno de incertidumbres (por ejemplo, no se sabe si finalmente las NU aprobarán o no la Carta Mundial, o en qué términos lo harán). Pero insisto en que el simple hecho de que existan instrumentos de derecho internacional que tengan como objeto el autogobierno local es ya de por sí un cambio importantísimo que, de nuevo, refleja la pérdida de soberanía de los Estados características de la globalización: los Estados ya cada vez van a ser menos soberanos en cuanto a su organización territorial interna, porque el Derecho internacional les obliga a respetar un mínimo de autogobierno para los municipios. Se les obliga a por lo menos un poco de descentralización municipal ${ }^{43}$.

\section{c) Las ciudades como incipientes sujetos de derecho internacional}

Ahora ya no se trata, como vimos en el apartado a), de que a las ciudades les vengan impuestas obligaciones por el derecho internacional. Se trata de que las ciudades, voluntariamente, asumen un papel activo en determinadas relaciones internacionales. Y es que, pese a que desde la estricta ortodoxia competencial establecida en las constituciones no disponen de ella, los municipios de hecho tienen política exterior y participan en según qué tipo de relaciones internacionales. Esta participación incluye la apertura de «oficinas» en otros países (destinadas a fomentar el comercio o el turismo), o fórmulas con poca trascendencia jurídica (aprobación de declaraciones de desnuclearización, de rechazo a la guerra, etc.), pero también, como señalan FRUG y BARRON (2006: 28), y sobre todo SINGH (2005), la «ratificación» por ciudades como San Francisco o Los Ángeles de la Convención de las NU para la eliminación de toda forma de discriminación contra las mujeres, o lo mismo por parte de Seattle o Salt Lake City respecto del Protocolo de Kyoto (ninguno de estos dos textos internacionales ha sido ratificado por los EEUU ${ }^{44}$. Muchas ciudades, que normalmente tienen

les y nacionales. Al respecto puede verse Francisco CAAMAÑo (ed.), La autonomía de los entes locales en
positivo. La Carta Europea de la Autonomía Local como fundamento de la suficiencia financiera, Fundación
Democracia y Gobierno Local, Madrid, 2003, así como Rafael FERNÁnDEZ MoNTALVO, «La presencia de la
Carta Europea de la Autonomía Local en los pronunciamientos jurisprudenciales sobre autonomía local de
2004», Anuario del Gobierno Local 2004, Fundación Democracia y Gobierno Local-Instituto de Derecho
Público, 2005. Pese a que de los 47 países miembros del Consejo de Europa 42 la han ratificado - y única-
mente seis países han aceptado la Carta en su integridad, sin reservas ni interpretaciones - lo esencial de su
contenido sí ha sido considerado vinculante por la mayoría de los países. 43 Del mismo modo que los derechos fundamentales representaron un avance gigantesco en el constitucionalismo del siglo 20, el autogobierno local - concebido, la igual que los derechos fundamentales, como derecho frente al poder, en este caso frente al poder estatal - va a transformar grandemente la estructura territorial del poder y el proceso de toma de decisiones. Por ello hoy se habla del «paradigma de la descentralización».

44 Cuando la resolución local - en este caso no de una ciudad sino del Estado de Massachussets - sí tenía consecuencias jurídicas mayores el asunto llegó a los tribunales: en la sentencia Crosby (2000) el Tribunal Supremo de los EEUU anuló una iniciativa de dicho Estado destinada a impedir la importación de productos de Birmania/Myanmar (para así castigar a los países que no hacían lo necesario para evitar el trabajo infantil, o los derechos de los trabajadores). El sentido de la sentencia estaba claro: el Congreso federal, y no los Estados, tiene competencia exclusiva respecto del comercio con los demás países. Sin embargo, como señalan 
problemas ambientales muy graves, y distintos de los del medio natural, han emprendido una política ambiental propia, distinta de la de los Estados a los que pertenecen - y a veces contradiciéndola ${ }^{45}$.

BLANK (2006a: 924 y 925) pone ejemplos de cómo ciudades — sobre todo en los EEUU - han tenido una política exterior muy activa respecto de boicots o embargos a Sudáfrica, Cuba, Nigeria. Del mismo modo, hay ciudades que, aprovechando un resquicio competencial del cual se carece en otros países, han establecido reglas sanitarias o de higiene muy avanzadas: prohibición de fumar en locales públicos, prohibición para los restaurantes de preparar y despachar platos preparados con cierto tipo de grasas consideradas nocivas para la salud ${ }^{46}$. Buena parte de estas medidas se adoptaron invocando recomendaciones o documentos técnicos de organismos internacionales como la Organización Mundial de la Salud (que de este modo pasaron de ser soft law a ser derecho «real» - por lo menos a nivel municipal).

Pero además del medio ambiente, donde mejor se aprecia esta actividad internacional de las ciudades es en su defensa de los derechos humanos. Algunas ciudades como Nueva York o San Francisco, o Barcelona o Tel Aviv, han emprendido políticas muy activas de defensa de los derechos humanos (en particular respecto de los inmigrantes, o del matrimonio homosexual, o adoptando reglas sobre salarios mínimos $)^{47}$. ¿Qué relación hay entre estas políticas municipales y el Derecho internacional? Es cierto que algunos de los derechos reconocidos a nivel municipal forman parte del sistema de derechos fundamentales de cada Estado. Pero normalmente las ciudades lo que pretenden con esta política es diferenciarse de los Estados de los que forman parte, reconociendo derechos sociales que no están reconocidos a nivel nacional (o que estándolo, no son recogidos por el legislador). Por ejemplo, el derecho a la vivienda, o políticas de igualdad, o de integración religiosa. En realidad, una de las más importantes justificaciones que las ciudades alegan para llevar a cabo estas políticas

FRUG y BARRON (2006: 28-29), esta sentencia no se refiere al tipo de iniciativas que están adoptando las ciudades (además de que no implica la participación de una ciudad sino de un Estado).

45 Sobre el tema en España puede verse Ángel B. GóMEZ PUERTO «Decálogo ambiental de las ciudades para el periodo de gobierno municipal 2007-2011», Actualidad Administrativa n. ${ }^{\circ} 10$ (2007), pág. 1164.

46 A finales de 2006 Nueva York fue la primera ciudad del mundo que prohibió el uso alimentario de grasas hidrogenadas (trans fat, en inglés). También en los Estados Unidos, con alto nivel de descentralización local, la potestad de prohibir fumar en los locales públicos esta en manos de los municipios, y prácticamente todos ellos la han aplicado en los últimos años.

47 Véase BLANK (2006a: 925). Este autor señala cómo las regulaciones administrativas de Nueva York o de San Francisco constituyen pequeñas cartas de derechos. Existen además ejemplos muy singularizados pero políticamente muy importantes: en abril de 2007 la Ciudad de México aprobó legalizar el aborto (en 2006 había aprobado las uniones homosexuales). En este caso no se trata de que una ciudad se salga del marco institucional y haga suya una declaración de derechos pensada en principio para Estados-naciones: se trata de que la Ciudad de México, que tiene un régimen institucional en la práctica equivalente al de los demás Estados de los Estados Unidos Mexicanos, haga uso de su autonomía política para regular un derecho fundamental (el de la vida o el del aborto, según se mire). 
es precisamente que el derecho que están protegiendo tiene un reconocimiento (directo o no) a nivel internacional. El derecho internacional de los derechos humanos les sirve como pretexto - cierto o no- para de alguna manera saltarse el marco nacional e ir más allá de lo que han ido las autoridades nacionales. Este «mirar para arriba» de las ciudades les sirve de coartada para establecer políticas activas de derechos humanos en ámbitos no cubiertos por la legislación del Estado al que pertenecen. Y ello incluso cuando el texto internacional en el que buscan el fundamento para su política es un texto desprovisto prácticamente de valor jurídico ${ }^{48}$.

En esta misma línea, y desde la consideración de la ciudad como el espacio en el que los ciudadanos ejercen la mayoría, cuando no la totalidad, de sus derechos, se registran varias iniciativas para recoger y sistematizar una especie de «carta de derechos en la ciudad», o incluso para dar forma aun «derecho a la ciudad $»^{49}$. Es, de momento, un experimento aun no dotado de fuerza normativa - ni siquiera podría calificárselo de soft law - pero en los próximos años probablemente dará lugar a desarrollos concretos.

\section{d) Las (redes de) ciudades como actores políticos internacionales}

Lo mismo que los países forman organizaciones o asambleas (con cesión o no de atributos de soberanía), las ciudades establecen federaciones. Se las suele conocer como «redes de ciudades». Sus orígenes se remontan a 1913 (con la Unión Internacional de Autoridades Locales) y 1957 (Carta de las Ciudades Unidas), y sus desarrollos más recientes son la declaración final de la Asamblea

\footnotetext{
48 Por ejemplo los derechos del peatón. El Parlamento Europeo aprobó el 12 de octubre de 1988 la llamada «Carta Europea de los Derechos del Peatón» (DOCE n. ${ }^{\circ}$ C-290 de 14 de noviembre de 1988), que no tiene ninguna fuerza vinculante y que establece principios amplísimos. Por lo pintoresco de sus afirmaciones, reproduzco aquí sus dos primeros artículos: «1.-El peatón tiene derecho a vivir en un ambiente sano y a disfrutar libremente del espacio público en las condiciones de seguridad adecuadas para su salud física y psicológica. 2. - El peatón tiene derecho a vivir en centros urbanos o rurales organizados a medida del hombre y no del automóvil, y a disponer de infraestructuras a las que se pueda acceder fácilmente a pie o en bicicleta». Los artículos 3 a 8 contienen previsiones para la infancia, los ancianos o los discapacitados, e incluso referidas a aspectos muy específicos del diseño del tráfico de vehículos. También se obliga, al parecer, a cambiar los sistemas de responsabilidad patrimonial («El peatón tiene derecho [...] a la introducción de un sistema de responsabilidad objetiva o de riesgo de modo que aquel que sea responsable de la creación de un riesgo asuma las consecuencias financieras (como, por ejemplo en Francia desde 1985)». Pues bien, esta carta ha sido «ratificada» por ciudades como Barcelona, estableciendo reglas organizativas y sustantivas para hacer efectivos estos derechos.
}

49 La llamada «Carta Mundial del Derecho a la Ciudad» fue discutida y apoyada por distintas entidades de derechos humanos, movimientos sociales, municipalidades gobiernos locales, gobiernos nacionales, foros nacionales de reforma urbana, universidades y organizaciones no gubernamentales presentes en el Foro Social de las Américas (Quito, Ecuador, en Julio de 2004) y en el Foro Mundial Urbano (Barcelona, España, en Septiembre de 2004). La carta se propone construir un modelo sustentable para la sociedad y el modo de vida urbano, basada en los principios de solidaridad, libertad, equidad, dignidad y justicia social. Véase una exposición de sus precedentes en Europa en Marcos VAQUER, «La Carta Europa de Salvaguarda de los Derechos Humanos en la Ciudad», Cuadernos de Derecho Local n. ${ }^{\circ}$ (2003), págs. 139 y ss. Paralelamente a esta iniciativa se registran otras similares (por ejemplo la de la Universidad de Valladolid, en España, 1lamada www.ciudad-derechos.org). 
Mundial de Ciudades y Autoridades Locales (Estambul, 1996) y la iniciativa lanzada en 1999 por el Banco Mundial y UN-Habitat: la Alianza de Ciudades (Cities Alliance $^{50}$. Estas dos iniciativas sin duda representaron un paso muy importante, pero tenían una característica que hacía que no fuese fácilmente aceptada por las principales ciudades. Tanto una como otra provenían de instituciones internacionales, acaso interesadas en aprovechar la cesión de soberanía (o la debilidad) de los países para fomentar el surgimiento de las ciudades como contrapoder a los países. Así que, dada su orientación y dadas sus limitaciones ${ }^{51}$, no llegó a ningún sitio, y su lugar fue pronto ocupado por otra organización promovida desde abajo por las ciudades: Unión de Ciudades y Gobiernos Locales (United Cities and Local Governments), constituida en París en 2004.

Como señalan FRUG y BARRON (2006: 25-26), esta nueva federación encuentra ante sí varios obstáculos, derivados esencialmente de la no fácil ubicación de las ciudades en el panorama internacional y de que compite por un espacio político que, como hemos visto, habían ocupado ya parcialmente poderosos organismos como el Banco Mundial o $\mathrm{NU}^{52}$. Nada más constituirse, la UCGL llegó a un acuerdo - pretendidamente paritario - con UN-HABITAT para desarrollar la agenda local del siglo 21, y desde entonces aspira a convertirse en órgano consultivo de las NU (de hecho hubo un informe de las NU, encabezado por el ex presidente de Brasil Cardoso, que recomendaba precisamente dotar de estatus oficial a la UCGL como órgano consultivo).

Estas redes tienen problemas existenciales importantes: por un lado critican el monopolio de poder internacional que tradicionalmente han desempeñado los Estados, pero por otro anhelan ejercer una parte de ese poder (y, al mismo tiempo, no desean verse fagocitadas por organizaciones como el Banco Mundial o las NU, o incluso como la UE). La aun pendiente decisión de las NU de institucionalizar a la UCGL como órgano permanente de consulta pone de relieve esta disyuntiva. Lo mismo ocurre en Europa con la rivalidad entre dos organismos oficiales o semioficiales (por lo demás bastante disfuncionales): el Comité de las Regiones (órgano institucional de la UE dominado por autoridades regionales, muy poderosas en países como Alemania, España, Italia y desde hace no mucho el Reino Unido ${ }^{53}$ ) y un órgano menor, el Consejo Europeo de Municipios y Regiones (que es la sección europea de la UCGL y en el que pre-

\footnotetext{
50 También hay que dar cuenta de la Hermandad Internacional de Ciudades (Sister Cities International), que une a más de 2.500 ciudades de 125 países, y de la Asociación Internacional de Responsables Municipales (International City/County Management Association), esta con un perfil no tan político y sí técnico o económico. Véanse un elenco más completo de organizaciones municipales en BLANK (2006a: 930-931).

51 En su Consejo de Dirección hay representantes del Banco Mundial, de NU, de gobiernos nacionales, de organismos financieros internacionales, y de UCGL. Pero no de las ciudades.

52 La UCGL tiene también problemas internos importantes: en su consejo directivo, llamado Metropolis, no están representada ninguna ciudad de los EEUU.

53 Sobre el Comité de las Regiones puede verse Antonio CALONGE, «El Comité de las Regiones y el futuro de Europa», Revista de Administración Local y Autonómica n. ${ }^{\circ}$ 300-301 (2006).
} 
dominan no las Regiones sino las ciudades y que, pese a ser financiado en parte por la Comisión Europea, no tiene estatus oficial en la UE).

\section{AUTOGOBIERNO LOCAL Y GLOBALIZACIÓN: ¿EL MERCADO COMO CENTRALIZACIÓN O COMO DESCENTRALIZACIÓN?}

Hoy ya casi nadie niega que las ciudades, una por una o agrupadas en organizaciones, representan un papel importante en la política de su país, o en la política mundial. Desde este planteamiento, han resultado beneficiarias de la globalización: no sólo porque la globalización ha coincidido en el tiempo con el reconocimiento a nivel internacional de una especie de derecho al autogobierno local, sino porque han aprovechado la indudable pérdida de poder y de soberanía de los Estados para alzar su voz a nivel internacional. Como dice SINGH (2005) parafraseando al juez BRANDEIS, las ciudades han sido el laboratorio - relativamente inocuo- en el que se han experimentado nuevas formas de gestión y se han roto buena parte de los moldes jurídicos tradicionales ${ }^{54}$. Naturalmente, ello no está exento de problemas desde el punto de vista jurídico, derivados esencialmente de la falta de adaptación del derecho internacional a la presencia de actores que no sean Estados u Organizaciones Internacionales ${ }^{55}$.

De lo hasta aquí expuesto parecería que la globalización ha beneficiado a las ciudades en cuanto a permitirles acceder a una presencia política y jurídica internacional que hasta ahora no tenían. En concreto, autores como BORJA TAMAYO (2000), FRUG y BARRON (2006: 59 a 62), RiVAS LEONE (2004: 83) o BLANK (2006a: 921) señalan que la globalización, es decir, la internacionalización de la economía, ha provocado una pérdida de poder de las autoridades centrales o federales y un aumento de la autonomía local frente a aquellas ${ }^{56}$. Y BoRJA Y CASTELLS (citados por RIVAS, 2004: 74) señalan que, habida cuenta de que el poder se ha desterritorializado o internacionalizado, la respuesta política y económica a la globalización ha de venir «de abajo», de instancias de poder próximas al ciudadano que en la medida de lo posible «territorialicen» las decisiones de los poderes públicos.

\footnotetext{
54 Ello ha producido otra de las manifestaciones del llamado soft law (véase DEL TORO, 2006).

55 Otros problemas sociales o políticos que la globalización esta acarreando a otras ciudades pueden verse en VARGAS HERNÁNDEZ (2005: 14 y ss.), singularmente la fractura local: solo aquellas ciudades grandes, con capacidad política y con capacidad de adaptación a la nueva realidad, estarían subiéndose al tren de la globalización y de sus efectos positivos, mientras que para otras ciudades la situación es la contraria, pues carecen de dicha capacidad. El autor critica la ausencia de contrapesos políticos y sociales que compensen esta mayor desigualdad territorial y social.

56 En realidad este fenómeno se podría ver como una especie de vuelta a los orígenes políticos del Estado, en la medida en que el Estado nació precisamente de las ciudades-Estado de la antigua Grecia (y otros Estados de surgimiento mucho más tardío se componían históricamente, como Alemania o Italia, de algunas ciudades-Estado).
} 
Sin duda llevan razón. Pero me parece que hay que matizar un poco.

De momento, siguiendo a VARGAS HERNÁNDEZ (2005: 30) es necesario plantearse - siquiera dejando en el aire la respuesta - si la descentralización derivada de la globalización equivale también a democratización. A juicio de este autor, la respuesta es casi siempre negativa, por lo menos en Latinoamérica, contradiciendo así la afirmación de los promotores internacionales de la descentralización - Banco Mundial, y otros - que sostienen la validez general de la equivalencia entre descentralización y democracia ${ }^{57}$. Por otro lado, la observación de BORJA Y CASTELLS es certera, pero parte de un presupuesto que no siempre se da: que las ciudades, o las administraciones subnacionales, estén en condiciones políticas, sociales, económicas, etc. para diseñar y llevar a cabo políticas públicas que contrarresten los efectos no ventajosos de la globalización.

En todo caso, a la pregunta de si la globalización genera mayores espacios de poder para las ciudades respecto de los Estados o de las regiones no creo que pueda darse una respuesta unívoca, probablemente porque no hay una única tendencia que predomine a nivel mundial. Según los autores antes citados (BorJa TAMAYO, Frug y BARRON, Rivas LeOne, Blank), la globalización $-\mathrm{y}$ no solo en zonas de alta integración económica (NAFTA) o de alta integración política y económica (la UE) - sí conduce a más autonomía local, por el creciente protagonismo político, económico o demográfico de las ciudades, por la difuminación de las tradicionales potestades de soberanía de los Estados y por la cada vez mayor equiparación - real o imaginaria - entre descentralización y democracia; como consecuencia de ello, las ciudades tendrían más autonomía respecto del Estado. Pero repito que se trata de dinámicas políticas aun difusas y sometidas a vaivenes políticos y económicos ${ }^{58}$.

En relación con el medio ambiente (una de las políticas más importantes hoy en día), BORJA TAMAYO (2000: 24) señala incluso que existe una relación directa entre incremento de la preocupación y de la protección ambiental y la necesidad de descentralización: sólo a nivel local puede gestionarse $-\mathrm{y}$ hasta cierto punto decidirse - una política ambiental efectiva.

Pero, ¿qué ocurre con la relación entre descentralización y mercado? Me parece que la respuesta a esta interrogante tal vez admita una respuesta más precisa, si reformulamos la pregunta del modo siguiente: la globalización, ¿da a las ciudades más autonomía o menos autonomía no frente a los poderes cen-

\footnotetext{
57 Otra postura crítica es la de VARGAS HERNÁNDEZ (2005: 31), quien escribe, refiriéndose a los TBI, APPRIs y a NAFTA, que «los acuerdos internacionales deben ser evaluados en función de sus contribuciones a la reducción de la pobreza».

58 Por ejemplo la relación entre economía de mercado (y apertura a la globalización) y descentralización. Países como China o Venezuela, con economías muy peculiares (muy dirigidas por el poder público) y hasta cierto punto opuestas a la globalización por determinadas políticas arancelarias o de precios, tienen un menor nivel de descentralización (como es notorio, en Venezuela se está produciendo una recentralización del poder territorial).
} 
trales sino frente al mercado? La respuesta no es difícil de imaginar: menos autonomía.

Y ello en varios sentidos: por la introducción de criterios economicistas en la gestión local (p. ej. control del endeudamiento), por la prohibición de desigualdades o de barreras al mercado único y a la circulación de capitales, o por lo que VARGAS HERNÁNDEZ (2005: 13) denomina «concentración de capital corporativo» frente al que muchos poderes locales no tienen apenas margen político de maniobra. También por un motivo, acaso consecuencia de lo anterior, que apuntan FRUG y BARRON (2006: 58 a 61): la consideración de las ciudades más como espacios de negocios que como colectividades humanas con capacidad de decisión sobre su propio destino. La competencia entre las ciudades por prestigio, presencia y capitales internacionales provoca - acaso involuntariamente - que sean vistas en el escenario internacional de la economía global más como mercados y como espacios de negocio (governance) que como gobiernos locales con agendas políticas y sociales y con intereses y necesidades que satisfacer (government). Para FRUG y BARRON, ello conduce a una cierta privatización de la ciudad ${ }^{59}$. Desde este punto de vista, algunas importantes resoluciones de arbitrajes internacionales como Metalclad o Tecmed, ya mencionadas mas atrás, pueden leerse en clave de favorecer aun más la mercantilización de las operaciones de las empresas con los poderes públicos ${ }^{60}$. El laudo Metalclad interpretó el capitulo 11 de NAFTA en el sentido de crear un derecho para el inversor extranjero a ser indemnizado por medidas que afecten negativamente a sus operaciones, su beneficio o sus expectativas de ganancia (derecho que surge de una controversia jurídica respecto de la existencia de una determinada potestad autorizatoria municipal, y que en otro caso no hubiese generado derecho a indemnización).

En cualquier caso, podemos decir que se han producido fenómenos muy diversos, que todos tienen en común una cosa: precisamente el recién mencionado escaso encaje de la proyección internacional de las ciudades tanto en el ordenamiento jurídico nacional como, sobre todo, en el derecho internacional. Pero bajo este común núcleo aparecen tendencias muy dispares. Por ejemplo la interioriza-

59 Ponen el ejemplo de SENNETT y su teorización del diseño urbano: a través de pautas de buena gobernanza, de saneamiento económico, de apertura a la competencia, etc., todas ellas impulsadas por el Banco Mundial y en general por las fuerzas de la globalización (y en muchas ocasiones asumidas por los propios responsables locales), las figuras de planeamiento urbano - particularmente la zonificación en cuadrícula, que maximiza el espacio - están suponiendo un corsé unificador -y por tanto negativo - de las dinámicas urbanas y sociales. De este modo se llega, dice SENNETT, a la «ciudad neutral». FRUG y BARRON sostienen que el DLI, con su visión de las ciudades como espacios de negocios abiertos a la competencia internacional, deja de lado otras prioridades de las ciudades que no interesan desde el punto de vista puramente económico.

60 En Metalclad (laudo arbitral del capítulo 11 NAFTA, del año 2000) se negó competencia al ayuntamiento de Guadalcázar (en el Estado de San Luis Potosí, en México) respecto de la autorización de un vertedero industrial. En Tecmed (laudo arbitral en el marco de un TBI entre México y España, del año 2004) se condenó a México por haber hecho dejación de sus poderes de intervención con el fin de respetar la oposición local al establecimiento de un vertedero industrial en el municipio de Hermosillo (Estado de Sonora). 
ción o internalización del derecho internacional (particularmente el derecho internacional ambiental, o el derecho internacional de los derechos humanos) por parte de las ciudades. $\mathrm{O}$ algo que hasta cierto punto va en sentido inverso: la internacionalización del derecho local de cada país (en la medida en que, como ya hemos visto, el autogobierno local está dejando de ser un asunto interno de los países para empezar a ser regulado por normas de derecho internacional).

Dentro de las gigantescas transformaciones que lleva aparejada la globalización hay una que tal vez merezca aquí algo de atención: es la llamada «glocalización», o «lugarización», o «glocalidad» (que es como lo denomina, entre otros, VARGAS HERNÁNDEZ, 2005: 11). Es decir, la mezcla de lo global y de lo local. Existen por lo menos dos nociones de lugarización: una «neutra» y otra «militante». La neutra es aquella que se fija en la adaptación de la globalización a las peculiaridades locales: sería la «aparición de fuerzas locales resultantes de un híbrido surgido de la adaptación, interpretación o traducción a nivel local de influencias globales» (BLANK 2006a, 927-928). Se habla de la adaptación de los bienes característicos de la globalización (ropa, comida, productos de tecnología) a los mercados locales, y en tal sentido es una estrategia «ofensiva» de las grandes multinacionales ${ }^{61}$. Y la noción «militante» sí concibe la lugarización como antitética a la globalización, y parte de la base de que es preciso hacer frente a la globalización y que, como señalaron hace tiempo CASTELLS Y BORJA, la democracia participativa local es el mejor (acaso el único) remedio para hacer frente a la globalización - porque, como afirman estos autores, es preciso oponerse al menos a los aspectos más negativos de la globalización. De este modo, se habla de lugarización como estrategia para que, mediante el comercio justo, los foros de ONGs, etc., las pequeñas comunidades se resistan a las tendencias supuestamente más negativas de la globalización. Estas es la tesis que encontramos, por ejemplo, en VARGAS HERNÁNDEZ (2005: 13 y ss.) o en RIVAS LEONE (2004: 71) ${ }^{62}$. Desde esta perspectiva, si la globalización entraña más autonomía local - por lo menos frente a los poderes centrales - entonces esta mayor autonomía local tal vez podría usarse como herramienta, para, desde «abajo», establecer contrapesos a la propia globalización.

Por otro lado, no se pierda de vista que, como hemos venido diciendo, algunos de los más importantes agentes de la globalización (por ejemplo el Banco Mundial, el Banco Interamericano de Desarrollo, o las NU) expresamente dicen favorecer la descentralización, como parte de su política de promoción de la democracia y de reforma del Estado - también para, se dice, acabar con esquemas de corrupción en algunos países, haciendo surgir más instancias de poder

\footnotetext{
61 Por ello este concepto de «lugarización» no es opuesto sino complementario a la globalización.

62 «Globalización y lugarización se presentan como dos procesos y fenómenos en continua contradicción y con enormes consecuencias en lo cultural, lo económico, lo social, etc. [...] Francisco GonZÁLEZ CRUZ señala que la lugarización está referida a la contrapartida a esa tendencia homogeneizadora, razón por la cual busca la identidad personal y local, y privilegia lo autóctono, lo vernáculo, lo natural y los singular, tendiendo a la heterogeneidad».
} 
que sirvan de contrapeso a los tradicionales poderes establecidos, normalmente a nivel central o federal, y que sean más susceptibles de control por la ciudadanía ${ }^{63}$. Pero al mismo tiempo limitan de alguna manera la descentralización, por lo menos desde el punto de vista económico, porque estas instituciones financieras quieren someter a control la capacidad de gasto y de endeudamiento de los entes territoriales (el caso de Europa es muy significativo, con la política y los objetivos de estabilidad presupuestaria ${ }^{64}$ ).

Finalmente, diré que esta cuestión del derecho al autogobierno local tiene implicaciones jurídico-técnicas muy complejas. Por ejemplo: ¿cómo se articula procedimentalmente la defensa por los municipios de este derecho? El borrador de Carta Mundial del Gobierno Local, y la CEAL, obligan a los Estados signatarios a establecer procedimientos en virtud de los cuales los municipios puedan defender ante los tribunales su derecho. Y no está claro que muchos Estados dispongan de estos procedimientos ${ }^{65}$. Más aun: si los municipios $-\mathrm{y}$ en general las Administraciones públicas - son titulares de derechos, tanto sustantivos como procedimentales, ¿pueden hacerlos valer mediante los mecanismos de amparo constitucional? La titularidad de las personas jurídico-públicas de derechos fundamentales es un aspecto que presenta problemas que, por lo menos en España, no están resueltos ${ }^{66}$.

63 Recordemos también la política de las NU de apoyar a las ciudades como actores políticos.

64 Sin duda, la limitación al gasto público, consecuencia del predominio de la ortodoxia monetaria frente a las políticas de gasto post-keynesianas, es una exigencia de la economía global. Se quiere evitar, sometiendo a control a las finanzas locales, que se repitan desastres como la bancarrota de Nueva York en 1975. Pero por otro lado al poder central no le viene mal que las ciudades estén en delicada situación financiera, para tenerlas controladas políticamente a cambio de suministrarles crédito. Tampoco les viene mal a los bancos, porque las ciudades les acabarán pidiendo préstamos (siempre que ofrezcan algún tipo de solvencia - medida en garantías patrimoniales). Sobre el principio de estabilidad presupuestaria en la UE puede verse, por todos, Roberto I. FERNÁNDEZ LÓPEZ «Las exigencias del Derecho comunitario europeo en materia de estabilidad presupuestaria y su repercusión en el poder financiero de las comunidades autónomas y las entidades locales», Cuadernos de Derecho Local n. ${ }^{\circ} 5$ (2004), págs. 107 y ss.

65 España reformó en 1999 (ley orgánica 7/1999 de 21 de abril) la ley reguladora de la jurisdicción constitucional (ley orgánica 2/1979 de 3 de octubre) con el objeto de permitir a los municipios - con grandes restricciones de legitimación procesal - acudir al Tribunal Constitucional para impugnar leyes regionales o nacionales que afectaran a su autonomía. Pero hasta hace muy poco no existía en España un único procedimiento formalizado de participación de los municipios en la toma de decisiones que les afectan. La ley 57/2003 de reforma de la legislación de régimen local (que dio nacimiento a la Conferencia Sectorial de Asuntos Locales), algunos acuerdos políticos del Presidente del Gobierno con la Federación de Municipios y Provincias, y la creación de órganos ad hoc previstos en los Estatutos de Autonomía fruto de las reformas de 2006-2007 (Consejo de Gobiernos Locales, en el Estatuto de Cataluña) han intentado establecer cauces mas o menos estables de participación, añadiéndose así a la tradicional participación a través de una muy poco eficaz comisión ministerial (la Comisión Nacional de Administración Local). Sobre el Consejo catalán puede verse Marc VILALTA, «Nuevas formas de participación de los entes locales: el Consejo de Gobiernos locales», Revista de Estudios Autonómicos y Federales n. ${ }^{\circ} 2$ (2006), págs. 225 y ss. Un aspecto parcial de esta participación puede verse en María J. GARCía GARCíA, «La intervención las entidades locales en el proceso de producción legislativa», Actualidad Administrativa 12 (2007), págs. 1420 y ss.

66 Para la cuestión en España véase Francisco VELASCO, Administraciones Públicas y derecho a la tutela judicial efectiva. La Administración como titular del derecho fundamental del art. 24.1 de la Constitución, Bosch, Barcelona, 2003. 


\section{BIBLIOGRAFÍA}

Blank, Yishai (2006a): The City and the World, Columbia Journal of Transnational Law, vol. 44, págs. 875 a 939.

Blank, Yishai (2006b): «Localism in the New Legal Order», 47 Harvard International Law Journal, págs. 263 y ss.

Borja TAMAYO, Arturo (2000): The New Federalism, Internationalization and Political Change in Mexico: A Theoretical Analysis of the Metalclad Case, working paper, CIDE, Mexico.

BREWER-CARIAS, Allan R. (2004): «Sobre la globalización, la lugarización y el pequeño municipio», Provincia. Revista Venezolana de Estudios Territoriales $\mathrm{n} .{ }^{\circ} 12$.

Brownlie, Ian (2003): Principles of Public International Law, Oxford University Press, $6 .{ }^{\mathrm{a}}$ ed.

Del Toro HuERTA, Mauricio Iván (2006): «El fenómeno del soft law y las nuevas perspectivas del derecho internacional», Anuario Mexicano de Derecho Internacional n. ${ }^{\circ} 6$.

FERnANDES, Edesio; VARLEy, Ann, eds. (1998): Illegal Cities: Law and Urban Changes in Developing Countries, Red Books, New York.

Friedmann, John (1995): «The World Cities Hypothesis», en Paul KnOX, Peter TaYlor (eds.) World Cities in a World System, Cambridge University Press.

FRUG, Gerald E.; BARRON, David J. (2006): «International Local Government Law», The Urban Lawyer vol. 28 n. ${ }^{\circ}$, págs. 1 a 62.

FrUG, Gerald E.; Ford, Richard T.; BARRON, David J. (2006): Local Government Law, Thomson/West, St. Paul, 4. ${ }^{\mathrm{a}}$ ed.

GONZÁLEZ OropeZA, Manuel (2006a): «Los municipios y el libre comercio. El caso Metalclad», SCLC/Estudios Jurídicos y Políticos, suplemento a n. ${ }^{\circ}$ 4. También en Manuel GoNZÁlez Oropeza, David Cienfuegos SALGAdo (coords.), El municipio en México, Laguna, México, págs. 317 a 326.

GreENE, Solomon J. (2003): «Staged Cities: Mega-Events, Slum Clearance, and Global Capital», 6 Yale Human Rights and Development Law Journal 161.

Gugler, Joseph, ed. (2004): World Cities Beyond the West: Globalization, Development, and Inequality, Cambridge University Press.

HERnÁndeZ BECERRA, Augusto (2004): «El municipio en tiempos de la aldea global», Provincia. Revista Venezolana de Estudios Territoriales $n .^{\circ} 12$.

MarCuSE, Peter; VAn KeMPEn, Ronald (2000): Globalizing Cities: A New Spatial Order?, Blackwell, London.

RIVAS LeONE, José Antonio (2002): «Los desafíos de la globalización y la reinvención del gobierno», Provincia. Revista Venezolana de Estudios Territoriales n. ${ }^{\circ}$, págs. 77 y ss.

RIVAS LEONE, José Antonio (2004): «Globalización, lugarización y buen gobierno. El papel de lo local», Provincia. Revista Venezolana de Estudios Territoriales n. ${ }^{\circ} 12$, págs. 67 y ss.

Sassen, Saskia (1991): The Global City: New York, London, Tokyo, Princeton University Press.

Sassen, Saskia (2006): Cities in a World Economy, Pine Forge Press, Oakland.

SASSEN, Saskia, ed. (2002): Global Networks, Linked Cities, Routledge, New York.

SAVITCH, H. V.; KANTOR, Paul (2002): Cities in the International Marketplace: The Political Economy of Urban Development in North America and Western Europe, Princeton University Press. 
LA INTERNACIONALIZACIÓN DE LAS CIUDADES (Y DEL RÉGIMEN MUNICIPAL)

SINGH, Shanna (2005): «Brandeis's Happy Incident Revisited: Cities as the New Laboratories of International Law», 37 George Washington International Law Review, págs. 537 a 557.

VARGAS HERNÁNDEZ, José Guadalupe (2005): «Implicaciones de los procesos de globalización económica en las reformas de las economías locales. Una perspectiva teórica», Provincia. Revista Venezolana de Estudios Territoriales n. ${ }^{\circ} 13$, págs. 9 y ss.

Velasco CABALlERo, Francisco (2006), «Subsidiariedad municipal en la organización territorial del Estado», SCLC/Estudios Jurídicos y Políticos n. ${ }^{\circ}$ 4, págs. 37 y ss.

WorLd BANK (2000): Cities in Transition: World Bank Urban and Local Government Strategy, Washington DC, 2000. 